
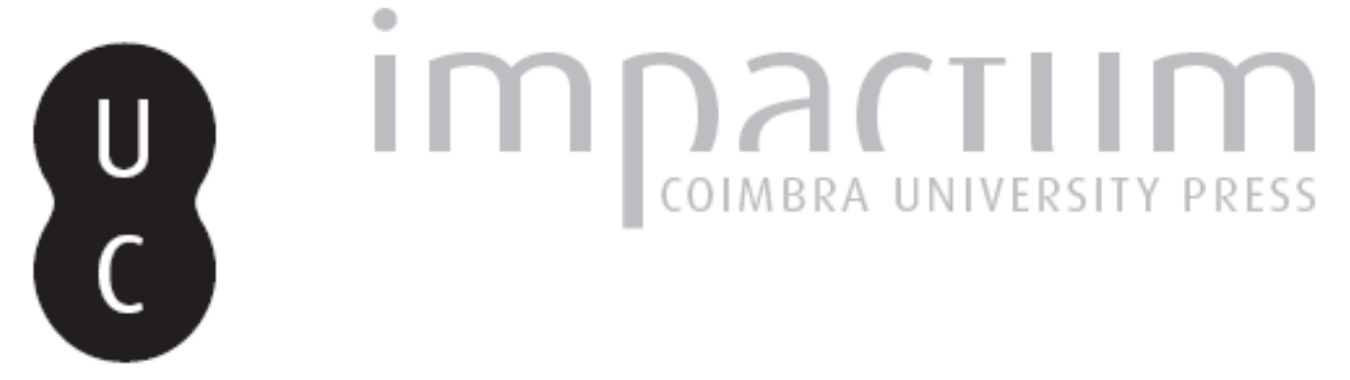

\title{
[Recensão a] Claude Longeon (ed.) - Étienne Dolet. Correspondance. Répertoire analytique et chronologique suivi du texte de ses lettres latines.
}

Autor(es): $\quad$ Rodrigues, Manuel Augusto

Publicado por: Imprensa da Universidade de Coimbra

URL persistente:

URI:http://hdl.handle.net/10316.2/45113

DOI:

DOI:https://doi.org/10.14195/2183-8925_7-2_25

Accessed : $\quad$ 26-Apr-2023 11:59:17

A navegação consulta e descarregamento dos títulos inseridos nas Bibliotecas Digitais UC Digitalis, UC Pombalina e UC Impactum, pressupõem a aceitação plena e sem reservas dos Termos e Condições de Uso destas Bibliotecas Digitais, disponíveis em https://digitalis.uc.pt/pt-pt/termos.

Conforme exposto nos referidos Termos e Condições de Uso, o descarregamento de títulos de acesso restrito requer uma licença válida de autorização devendo o utilizador aceder ao(s) documento(s) a partir de um endereço de IP da instituição detentora da supramencionada licença.

Ao utilizador é apenas permitido o descarregamento para uso pessoal, pelo que o emprego do(s) título(s) descarregado(s) para outro fim, designadamente comercial, carece de autorização do respetivo autor ou editor da obra.

Na medida em que todas as obras da UC Digitalis se encontram protegidas pelo Código do Direito de Autor e Direitos Conexos e demais legislação aplicável, toda a cópia, parcial ou total, deste documento, nos casos em que é legalmente admitida, deverá conter ou fazer-se acompanhar por este aviso.

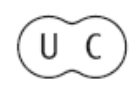




\section{REVISTA DE HISTORIA DAS IDEIAS 7}

\section{REVOLTAS E REVOLUCOẼS}

\section{**}

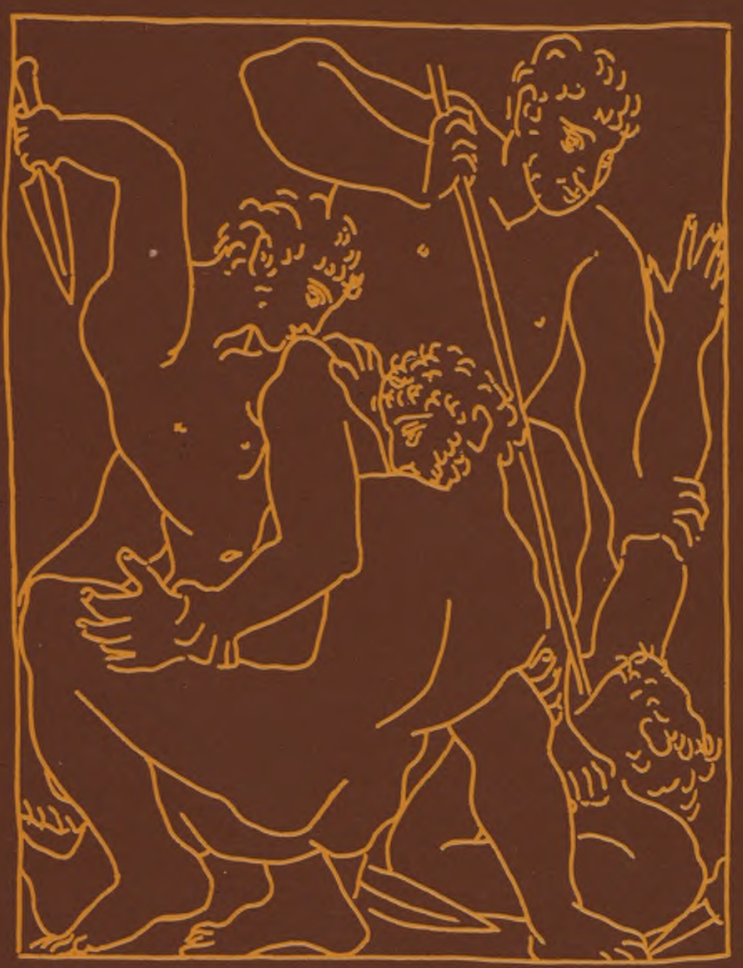

INSTITUTO DE HISTÓRIA E TEORIA DAS IDEIAS FACULDADE DE LETRAS 
José V. de Pina Martins (ed.) — Damião de Góis, humanista européen. École Pratique des Hautes Études, IV Section, Centre de Recherches sur le Portugal de la Renaissance, Études I. Braga, Barbosa \& Xavier, 1982. XLII + 357 p.

Para assinalar o $4 .^{\circ}$ centenário da morte do grande humanista português (1574), foi editada esta valiosa obra que encerra trabalhos de Marcel Bataillon (cuja morte entretanto ocorreu) sobre a vida de Góis; de Jean-Claude Margolin sobre a influência de Erasmo no pensador português e seu significado; de Jorge Borges de Macedo sobre o lugar que Góis ocupa na historiografia portuguesa; de Jean Aubin acerca da influência exercida pelos seus encontros e pela amizade com o arcebispo de Upsala, Johannes Magnus, e seu irmão Olaus, e da defesa daí resultante da causa dos Etíopes e dos Lapões; e de Isaías da Rosa Pereira sobre o processo inquisitorial em 1571-72, em que os seus encontros com Lutero e Melanchton causaram sensação, embora na perspectiva do autor não haja indícios de adesão à Reforma, apesar de ter sido condenado a prisão perpétua num mosteiro após reconciliação.

\section{Manuel Augusto Rodrigues}

Claude Longeon (ed.) - Étienne Dolet. Correspondance. Répertoire analytique et chronologique suivi du texte de ses lettres latines. Travaux d'Humanisme et Renaissance, n. ${ }^{\circ} 188$, Genève, Droz, 1982. 251 p.

Claude Longeon tem dedicado a Dolet alguns dos seus trabalhos, como Documents d'archives, 1977; Préfaces françaises d'Étienne Dolet, 1979; e Bibliographie d'Étienne Dolet, écrivain, éditeur et imprimeur, 1979. Todos eles foram acolhidos pelos especialistas com aplauso. Também esta sobre a correspondência de Dolet merecerá certamente o maior apreço, atendendo à maneira como é apresentada, com notas históricas e críticas muito bem elaboradas e uma clareza digna de louvor. Ao todo são 94 as cartas latinas de Dolet apresentadas, que vão de Agosto de 1532 (período toulousano) a Julho de 1544 (período lionês). $\mathrm{O}$ leitor tem agora à sua disposição um excelente guia $\mathrm{e}$ um novo instrumento de trabalho que the possibilita o estudo apurado da figura e do pensamento de Dolet. 